\title{
Advances in stent technologies and their effect on clinical efficacy and safety
}

This article was published in the following Dove Press journal:

Medical Devices: Evidence and Research

3 June 2014

Number of times this article has been viewed

\author{
Navin Nikam \\ Toby B Steinberg \\ Daniel H Steinberg \\ Division of Cardiology, Medical \\ University of South Carolina, \\ Charleston, SC, USA
}

Correspondence: Daniel H Steinberg Division of Cardiology, Medical University of South Carolina,

25 Courtenay Drive, ART 7058

MSC 592, Charleston, SC 29425, USA

Email steinbe@musc.edu

\begin{abstract}
The introduction of intracoronary stents represented a major advance in interventional cardiology. While bare metal stents set the benchmark for improved safety over angioplasty, intimal hyperplasia and subsequent restenosis were important limitations. First-generation drugeluting stents demonstrated significant improvements in efficacy, but not necessarily safety, and further technologic developments have focused on optimizing both. Current advances and understanding in stent design continue to improve on these concepts. This review summarizes past and present technology with particular emphasis on the principles underlying the efficacy and safety of drug-eluting stents, and offers a glimpse into the next generations of stents aimed at treating symptomatic coronary artery disease.
\end{abstract}

Keywords: drug-eluting stents percutaneous coronary intervention, coronary artery disease, bioabsorbable polymers, bioabsorbable struts, polymer free

\section{Background}

Balloon angioplasty has been an important treatment modality for symptomatic coronary artery disease since the early 1980s when the earliest registries demonstrated effective angina reduction and acceptable safety. ${ }^{1}$ Important limitations included acute closure rates up to $6 \%$ and restenosis rates up to $30 \%$, and these served to fuel innovation in technique and technology over the ensuing decades. ${ }^{2,3}$ The advent of bare metal stents significantly reduced periprocedural complications, but bare metal stents did not have an overly profound impact on restenosis rates. Additionally, stent thrombosis emerged as an important and potentially fatal complication. ${ }^{4,5}$ The addition of antiproliferative agents to metal stents significantly reduced restenosis rates to $<5 \%,{ }^{6-8}$ thus leading to a wave of enthusiasm and technologic advances to extend drug-eluting stent (DES) usage into increasingly complex patient and lesion subsets. This enthusiasm was tempered somewhat by the specter of very late stent thrombosis, a rare but significant complication with an incidence of $0.3 \%-0.6 \%$ per year and no definitive plateau. ${ }^{9,10}$ As a result, each advance in stent technology now encompasses a combined approach of optimal efficacy (deliverability/restenosis) and safety (stent thrombosis). This review focuses on the evolution of stent design and drug delivery platforms comprising our current and potential future armamentarium in percutaneous coronary intervention.

\section{Stent design}

The DES has three main components, ie, the scaffold or struts, the drug, and a polymer (Figure 1 and Table 1). Each serves an important role in the function of the stent. 


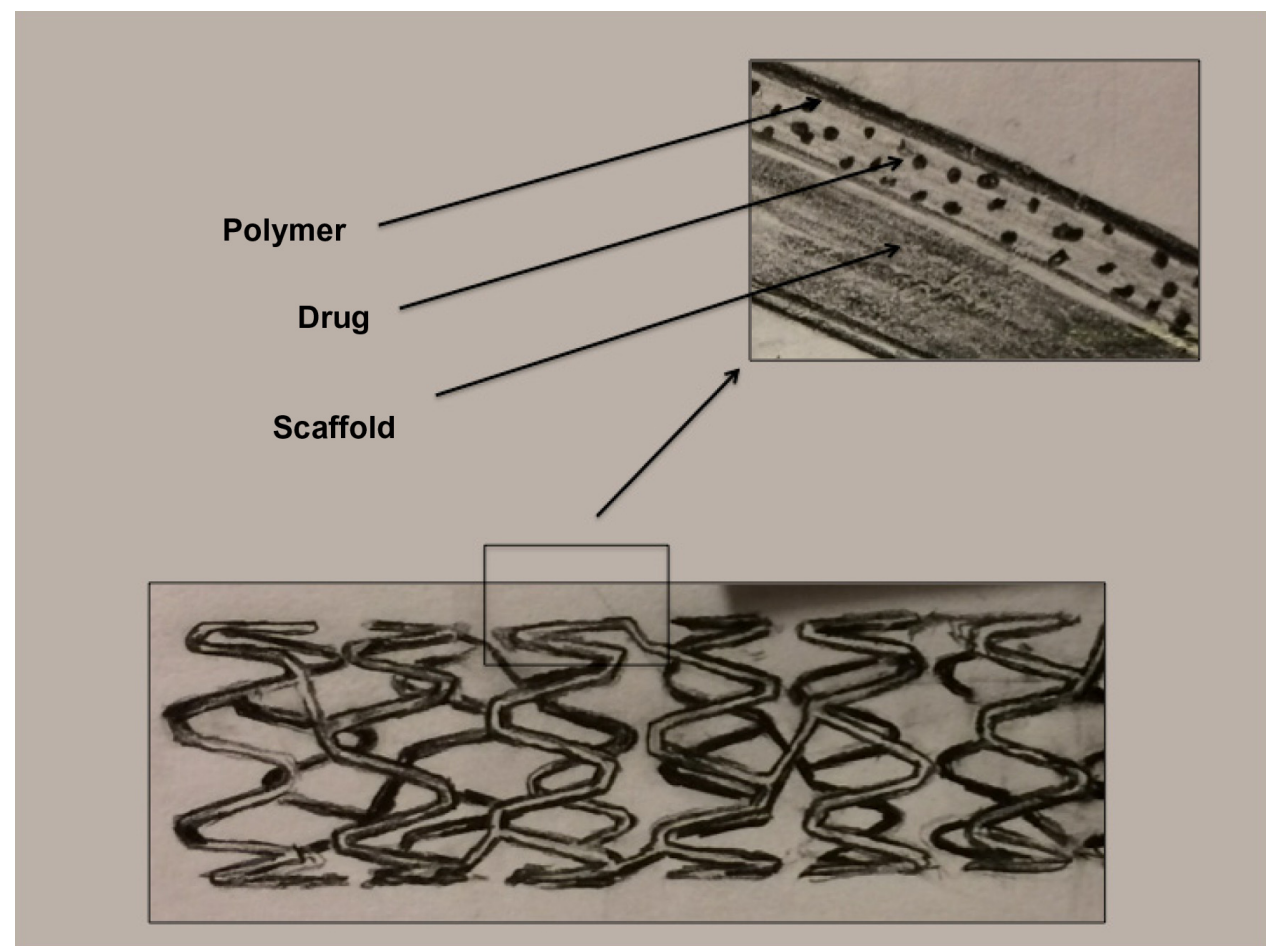

Figure I Components of a drug-eluting stent.

Note: The metal scaffold is coated with an antiproliferative drug and a polymer to regulate drug elution.

Additionally, iterative advances in each component can have a potential influence on both efficacy and safety. Stents have loosely been defined in generations based on iterative design changes. For the purposes of this paper, we define those generations as listed in Table 2.

\section{Scaffold}

The original bare metal stents were composed of a $316 \mathrm{~L}$ stainless steel alloy composed of iron, nickel, and chromium. First-generation DES (Cypher; Cordis Corporation, Miami Lakes, FL, USA, and TAXUS Express, Boston Scientific,

Table I Durable polymer stents

\begin{tabular}{|c|c|c|c|c|c|c|}
\hline Drug & Stent & Stent base & Strut thickness $(\mu \mathrm{m})$ & Polymer & Drug elution & Manufacturer \\
\hline \multirow[t]{3}{*}{ Sirolimus } & Cypher & $316 \mathrm{LSS}$ & 140 & Parylene C & 60 days & Cordis \\
\hline & & & & PEVA & & \\
\hline & & & & PBMA & & \\
\hline \multirow[t]{3}{*}{ Paclitaxel } & TAXUS express & $316 \mathrm{LSS}$ & 132 & SIBS & 30 days & Boston Scientific \\
\hline & TAXUS liberté & $316 \mathrm{LSS}$ & 81 & SIBS & 30 days & Boston Scientific \\
\hline & TAXUS element & $\mathrm{PtCr}$ & 81 & SIBS & 30 days & Boston Scientific \\
\hline \multirow[t]{7}{*}{ Zotarolimus } & Endeavor & $\mathrm{CoCr}$ & 91 & Phosphorylcholine & 2 weeks & Medtronic \\
\hline & Resolute & $\mathrm{CoCr}$ & 91 & Hydrophobic $\mathrm{ClO}$ & $85 \%$ by 60 days & Medtronic \\
\hline & & & & PVP & & \\
\hline & & & & Hydrophilic $\mathrm{Cl} 9$ & & \\
\hline & Resolute Integrity & $\mathrm{CoCr}$ & 91 & Hydrophobic ClO & $85 \%$ by 60 days & Medtronic \\
\hline & & & & PVP & & \\
\hline & & & & Hydrophilic CI9 & & \\
\hline \multirow[t]{5}{*}{ Everolimus } & Xience V/Promus & $\mathrm{CoCr}$ & 81 & PVDF-HRP & $80 \%$ by 30 days & Abbott Vascular \\
\hline & & & & PBMA & & \\
\hline & Promus element & $\mathrm{PtCr}$ & 81 & PVDF-HRP & $80 \%$ by 30 days & Boston Scientific \\
\hline & and promus premiere & & & & & \\
\hline & & & & PBMA & & \\
\hline
\end{tabular}

Abbreviations: $\mathrm{CoCr}$, cobalt chromium; PtCr, platinum chromium; PEVA, polyethylene-co-vinyl acetate; PBMA, poly n-butyl methacrylate; SIBS, poly (styrene-b-isobutyleneb-styrene); PVP, polyvinyl pyrrolidone; PVDF-HRP, polyvinylidene fluoride-co-hexafluoropropene; SS, stainless steel. 
Table 2 Stent generations

\begin{tabular}{lll}
\hline Generation & Characteristics & Examples \\
\hline First & Bare metal devices & Cypher \\
& & Taxus \\
Second & Cobalt chromium devices & $\begin{array}{l}\text { Endeavor } \\
\text { Xience/Promus }\end{array}$ \\
& & $\begin{array}{l}\text { Resolute } \\
\end{array}$ \\
& & Resolute Integrity \\
Third & Platinum chromium devices & TAXUS Element \\
& & Promus Element \\
& & Promus Premier \\
Fourth & Bioabsorbable devices & \\
& Polymer-free devices & BioFreedom \\
& & Cre8 \\
\hline
\end{tabular}

Natick, MA, USA) were built on the platforms of each manufacturer's respective bare metal stent, ie, Bx Velocity and Express. These stents were suboptimal with regard to visibility, potential for allergic response, and deliverability. ${ }^{11}$ The latter issue was thought to be influenced by the thickness of each stent $(132 \mu \mathrm{m}$ for the TAXUS Express and $140 \mu \mathrm{m}$ for the Cypher). In the ISAR STEREO (Intracoronary Stenting and Angiographic Results: Strut Thickness Effect on Restenosis Outcome) study, Kastrati et al demonstrated that strut thickness influenced long-term efficacy. A reduction in strut thickness in two similarly designed 316L stainless steel stents (50 $\mu \mathrm{m}$ versus $140 \mu \mathrm{m}$ ) achieved a $42 \%$ relative risk reduction in angiographic restenosis and a 38\% risk reduction in repeat target vessel revascularization at one year. ${ }^{12}$ These findings were even more significant when stents of different design were compared. ${ }^{13,14}$ However, some of the drawbacks of the thinner 316L stainless steel alloy included less successful delivery and reduced angiographic visibility. ${ }^{13}$

Cobalt chromium ( $\mathrm{CoCr}$ ) was the first of two metal alloys developed to address these issues and defines our second generation of DES. Having been previously used in other medical implants, $\mathrm{CoCr}$ had already demonstrated good biocompatibility. ${ }^{15} \mathrm{~A}$ modest increase in density from $8.0 \mathrm{~g} / \mathrm{cm}^{3}$ for $316 \mathrm{~L}$ stainless steel to $9.1 \mathrm{~g} / \mathrm{cm}^{3}$ for the L605 CoCr (Vision BMS, Abbott Laboratories, Abbott Park, IL, USA) and $8.4 \mathrm{~g} / \mathrm{cm}^{3}$ MP35N (Driver BMS, Medtronic Inc., Minneapolis, MN, USA) led to a similarly modest improvement in visibility. ${ }^{16}$ The higher yield and tensile strength of the $\mathrm{CoCr}$ alloy allowed for thinner struts while maintaining adequate radial strength suitable for percutaneous coronary intervention. ${ }^{11,17}$ However, this alloy is associated with greater stent recoil due to higher elastic properties with increased potential for malapposition and under-expansion of the stent. ${ }^{16,17} \mathrm{CoCr}$ is currently the strut base for the Xience/Promus platforms (strut thickness $81 \mu \mathrm{m}$ ) and the Endeavor platforms (91 $\mu \mathrm{m})$. The Resolute Integrity (Medtronic Inc.) is the latest $91 \mu \mathrm{m}$ strut made from a single strand of CoCr alloy on the design idea of continuous sinusoid technology to optimize deliverability and radial strength. ${ }^{18}$

Platinum chromium (PtCr) is another advance in strut alloys, and it defines our third generation of stents. The yield and tensile strengths are higher than for $316 \mathrm{~L}$ stainless steel and comparable with $\mathrm{CoCr}$, which allows for thinner stent struts. Additionally, it has elastic properties similar to stainless steel, so is associated with less recoil during stent placement. ${ }^{16,17}$ With a density of $9.9 \mathrm{~g} / \mathrm{cm}^{3}$, a $33 \% \mathrm{PtCr}$ alloy confers improved visibility. ${ }^{16}$ Early studies have demonstrated the efficacy of PtCr platforms compared with historical controls, and additional clinical trials have demonstrated noninferiority of $\mathrm{PtCr}$ alloys compared with current secondgeneration CoCr DES..$^{19,20}$

In contrast with its competitors, the PtCr platform has been associated with an increased risk of longitudinal deformity resulting in longitudinal stretching or shrinking and possible malapposition. This may be a result of efforts to make stents thinner, flexible, and more deliverable, and therefore be more related to stent design rather than the alloys. ${ }^{21}$ Bench testing suggests that the $\mathrm{PtCr}$ Element platform may be at higher risk, although this complication has been seen with all newer stents. ${ }^{22}$ To address this concern, the Promus Element was modified to include additional connectors between rows near the proximal end of the stent (Promus Premier), and early results suggest reduced rates of longitudinal deformity. ${ }^{23}$

Bioabsorbable stent platforms potentially represent the next generation of technology, and the idea is intuitively attractive for many reasons. Poly-L-lactic acid (PLLA) has previously been used in numerous medical devices and demonstrated predictable degradation kinetics and good safety in previous coronary applications. ${ }^{24,25}$ It is the basis for the BVS (bioresorbable vascular scaffold) stent (Abbott Vascular, Abbott Park, IL, USA) and will be discussed later. Other absorbable platforms in clinical trials include a tyrosinederived polycarbonate polymer and magnesium-based stents, and they have been reviewed elsewhere. ${ }^{26}$

\section{Polymers}

Polymers serve a dual purpose of providing a barrier between the tissue and stent struts, and timing release of an antiproliferative drug. Once the drug is fully eluted, the original, durable polymers remain behind and continue to interact with the vascular endothelium. Studies have shown that 
polymers may contribute to late stent thrombosis, neointimal hyperplasia, hypersensitivity, and restenosis.

Polymers can be divided into two categories, ie, passive and active. Passive polymers provide a barrier-like coating to enhance the biocompatibility of stents. Historically, these polymers were composed of inorganic inert components, such as heparin, gold, carbon, and silicon carbide, and they failed to show a significant improvement over bare metal stents with regard to restenosis. ${ }^{27}$

On the other hand, active coatings are capable of eluting a localized drug effect over a finite period of time. The coatings themselves can be permanent or temporary. Early-generation DES included permanent types of active polymers in their stent design, and elution kinetics were one of the key drivers for polymer selection. ${ }^{28}$ The Cypher stent incorporated a three-layer polymer starting with parylene $\mathrm{C}$, a hydrophobic and biocompatible layer attached to the metallic surface. This was followed by polyethylene-co-vinyl acetate (PEVA) and poly-n-butyl methacrylate (PBMA) mixed with sirolimus, and a final third layer of PEVA/PBMA to slow early elution, resulting in a total elution period of 60 days. ${ }^{11,28}$ The TAXUS Express stent utilized a polystyrene-b-isobutylene-b-styrene copolymer to elute paclitaxel with no top layer leading to a 30-day elution period. ${ }^{11,28}$

Histologic studies performed at autopsy of first-generation DES showed evidence of hypersensitivity (immunoglobulin E-mediated reactions), which had not been previously seen in bare metal stents studies or known to occur with the antiproliferative agents being used. ${ }^{29}$ Although inconclusive from this type of study, the polymers were implicated as a contributing factor in stent thrombosis. In an autopsy study, inflammatory cells found around fragments of polymers on pathology suggested that the polymer was a possible mediator of stent thrombosis. ${ }^{30}$ Additionally, a larger autopsy series showed that DES with late stent thrombosis had evidence of delayed arterial wall healing, again with the presence of inflammatory cells. ${ }^{31}$

Safety concerns and biocompatibility became more important drivers of polymer selection with next-generation products. As a result, efforts were geared to reducing polymer-induced hypersensitivity. An early porcine model looking at five biodegradable and three permanent polymers in the absence of an antiproliferative drug showed that both polymer types can cause significant vessel inflammation and neointimal thickening. ${ }^{32}$ Of note, the polylactic acid/ polyglycolic acid copolymer showed the least amount of fibrocellular proliferation, ${ }^{32}$ and its subunits polyglycolic acid (PGA) and polylactic acid (PLA, also known as PLLA), are some of the bioabsorbable polymers being utilized in bioabsorbable products.

Phosphorylcholine is a unique passive biomimicry polymer that also has active characteristics, making it an attractive option for drug elution. ${ }^{28}$ Phosphorylcholine is a naturally occurring component of cell membrane structure and demonstrates excellent biocompatibility. A key benefit of phosphorylcholine is its ability to reduce adhesion of platelets and inflammatory cells, $;^{33}$ as well as its compatibility with other chemical compounds. Phosphorylcholine was the polymer utilized in the second-generation $\mathrm{CoCr}$ zotarolimus-eluting Endeavor stent (Medtronic Inc.), ${ }^{34}$ but the rapid elution kinetics of the phosphorylcholine polymer and resultant late lumen loss proved to be a significant limitation and led to a redesign of the Endeavor platform. This fact illustrated how characteristics such as the kinetics of polymer degradation still play an important role in polymer selection and stent design. ${ }^{35}$

\section{Drugs}

There was no arguing that first-generation DES were associated with significant reductions in neointimal hyperplasia and in-stent restenosis; $;^{7,836}$ however, the possibility of the drugs contributing to delayed arterial healing and late stent thrombosis could not be ignored. In an animal model, paclitaxel was shown to have an inverse and dose-dependent relationship with late lumen loss, which was also associated with increased medial wall necrosis. ${ }^{37}$ Sirolimus was associated with increased inflammation and fibrin deposits, as well as delayed endothelialization. ${ }^{38}$

It has also been noted that the more lipophilic the drug, the less drug lost upon exposure to blood and the easier it will transmit through the hydrophobic vessel wall. ${ }^{37}$ Newer agents such as everolimus, zotarolimus, and Biolimus (Biosensors International Pte Ltd, Singapore) are sirolimus analogs that may benefit from being more lipophilic. ${ }^{39,40}$ Everolimus and zotarolimus have also been shown to inhibit proliferation of coronary arterial smooth muscle cells, thereby possibly reducing neointimal formation. ${ }^{39,41}$ Again, long-term studies will show if these agents can outperform currently approved drugs.

\section{Stent evolution in clinical trials}

Despite some limitations, first-generation DES demonstrated excellent efficacy and safety profiles when compared with bare metal stents. It therefore makes sense that each successive advancement or improvement in stent technology would incorporate the conceptual advances of the previous generation. As a result, second-generation 
and third-generation stents represent more of an iterative advance than a complete paradigm shift. Comparative studies of established platforms with novel designs therefore do not necessarily demonstrate the overwhelming benefit seen with DES when they were first studied. We will review the iterative stent advancements focusing on the determinants that drove the clinical benefit.

\section{Second-generation cobalt chromium DES} Zotarolimus-eluting stent

Endeavor (Medtronic Inc.), a $91 \mu \mathrm{m}$ CoCr strut with a phosphorylcholine biocompatible polymer that eluted zotarolimus over a 2-week period, was the first commercially available zotarolimus-eluting stent (ZES). Figure 2 and Table 3 summarize some of the pivotal clinical trials evaluating the Endeavor stent. ENDEAVOR II (Randomized, Double-Blind, Multicenter Study of the Endeavor Zotarolimus-Eluting Phosphorylcholine-Encapsulated Stent for Treatment of Native Coronary Artery Lesions) compared the Endeavor ZES platform with a bare metal stent and showed a significant improvement in target vessel failure (target vessel revascularization, myocardial infarction [MI], target vesselrelated cardiac death) driven primarily by a $55 \%$ relative risk reduction in target vessel revascularization at 9 months. ${ }^{34}$ A $61 \%$ relative risk reduction in target lesion revascularization ( $4.6 \%$ versus $11.8 \%, P=0.0001)$ was also seen at 9 months, and improvements in target vessel failure and target lesion revascularization persisted at 5 years. ${ }^{42}$ ENDEAVOR IV (Randomized Comparison of Zotarolimus and PaclitaxelEluting Stents in Patient with Coronary Artery Disease) showed noninferiority of the ZES to the paclitaxel-eluting stent (PES) for target vessel failure (cardiac death, MI, target vessel revascularization) at 9-month follow-up. ${ }^{43}$ Long-term follow-up found similar rates of target lesion revascularization $(6.5 \%$ versus $6.1 \%, P=0.662)$ with an improvement in rates of cardiac death, MI, and very late stent thrombosis, $(0.1 \%$ versus $1.6 \%, P=0.004)$, favoring the Endeavor. ${ }^{44}$ However, when the ZES was compared with the sirolimus-eluting stent (SES) in ENDEAVOR III (Comparison of Zotarolimus-Eluting and Sirolimus-Eluting stents in Patients With Native Coronary Artery Disease), the results were not as convincing regarding its improvement over first-generation DES. ${ }^{45}$ ENDEAVOR III favored the SES platform for both late lumen loss and binary restenosis ( $11.7 \%$ versus $4.3 \%, P=0.04$ ). SORT OUT III (Scandinavian Organization for Randomized Trials with Clinical Outcome III) was a larger trial comparing the ZES and SES, and this also demonstrated superior major adverse cardiac events (MACE, ie, cardiac death, MI, target vessel revascularization), ( $6 \%$ versus $3 \%, P=0.0002)$, driven by both $\mathrm{MI}$ and target vessel revascularization. ${ }^{46}$ These results persisted at 3 years, with MACE $(12.9 \%$ versus $10.1 \%, P=0.022)$ driven by $40 \%$ higher target vessel revascularization in the Endeavor platform and no improvement in definite stent thrombosis $(1.1 \%$ versus $1.4 \%, P=0.61) .{ }^{47}$ Interestingly, the 5-year follow-up to ENDEAVOR III found that MACE rates favored the thin strut CoCr ZES over SES (14\% versus 22\%, $P=0.05)$ and that secondary endpoints such as target lesion revascularization, target vessel revascularization, and stent thrombosis was similar between the two groups. ${ }^{48}$

One of the reasons for the decreased effectiveness of the Endeavor stent within the first year was thought to be due to the

\section{Clinical TLR within 12 months vs ZES}

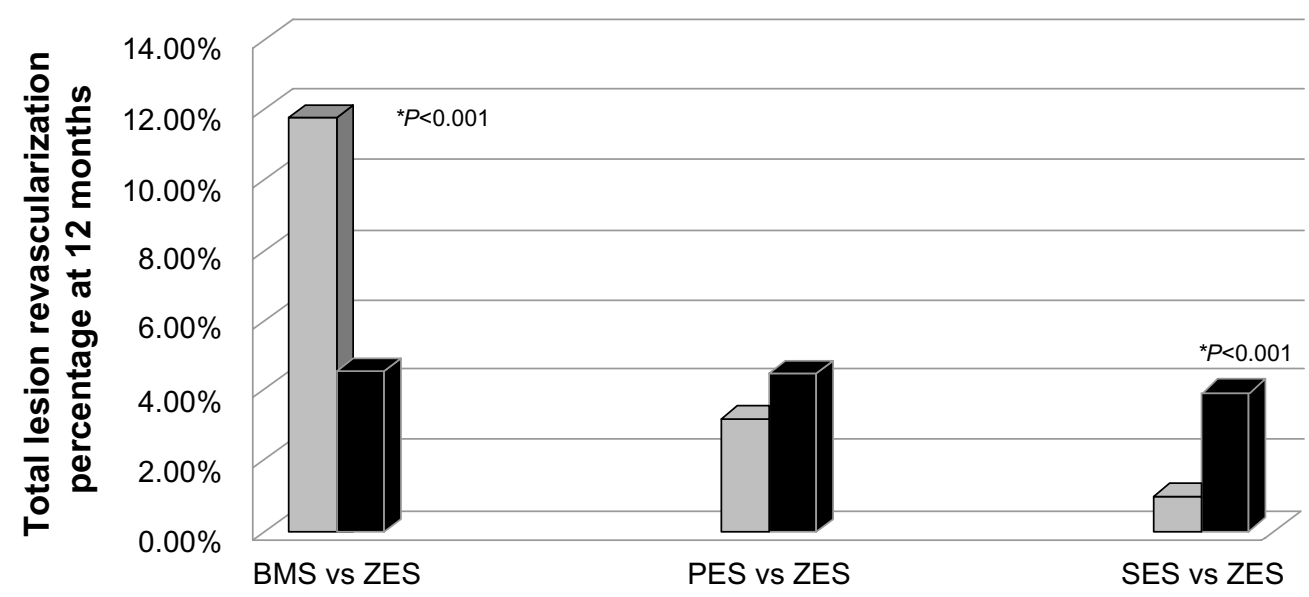

Figure 2 Trials of the ZES stent (Endeavor II, IV, SORT OUT III). ${ }^{34,43,46}$

Notes: ${ }^{*} P<0.05$; data from Fajadet et al; ${ }^{34}$ Leon et al; ${ }^{43}$ Rasmussen et al. ${ }^{46}$

Abbreviations: BMS, bare metal stent; SES, sirolimus-eluting stent; PES, paclitaxel-eluting stent; ZES, zotarolimus-eluting stent; TLR, target lesion revascularization; vs, versus. 
Table 3 ZES outcomes in large trials

\begin{tabular}{|c|c|c|c|c|c|}
\hline Study & Endpoint & Time frame & Comparator & ZES & $P$-value \\
\hline \multirow[t]{3}{*}{ ENDEAVOR $\|^{34}$ (BMS) } & TVF* & 9 months & $15.1 \%$ & $7.9 \%$ & 0.0001 \\
\hline & TLR & 9 months & $11.8 \%$ & $4.6 \%$ & 0.0001 \\
\hline & ST & 9 months & $1.2 \%$ & $0.5 \%$ & 0.224 \\
\hline \multirow[t]{3}{*}{ ENDEAVOR IV 43 (PES) } & TVF* & 9 months & $7.1 \%$ & $6.6 \%$ & 0.685 \\
\hline & TLR & 12 months & $3.2 \%$ & $4.5 \%$ & 0.228 \\
\hline & ST & 12 months & $0.1 \%$ & $0.9 \%$ & 0.07 \\
\hline \multirow[t]{3}{*}{ SORT OUT III' (SES) } & MACE* & 9 months & $3 \%$ & $6 \%$ & 0.0002 \\
\hline & TLR & 9 months & $1 \%$ & $4 \%$ & $<0.00 \mathrm{I}$ \\
\hline & ST & 9 months & $<1 \%$ & $1 \%$ & 0.048 \\
\hline
\end{tabular}

Note: *Primary outcome.

Abbreviations: MACE, major adverse cardiac events; TVF, target vessel failure; TLR, target lesion revascularization; ST, stent thrombosis; BMS, bare metal stent; PES, paclitaxel-eluting stent; SES, sirolimus-eluting stent; ZES, zotarolimus-eluting stent.

early release kinetics of phosphorylcholine. ${ }^{49} \mathrm{~A}$ second version of the Endeavor, the Endeavor Resolute (Medtronic Inc.), was engineered to have a longer drug elution time by utilizing a new biocompatible polymer named BioLinx. BioLinx consists of three polymers, ie, a hydrophobic C10 polymer to help control drug release, a polyvinyl pyrrolidone to enhance initial drug delivery, and a $\mathrm{C} 19$ hydrophilic layer for biocompatibility. The polymer elutes $85 \%$ of the zotarolimus in 60 days and the rest by 180 days. ${ }^{49} \mathrm{~A}$ third iteration, Resolute Integrity (Medtronic Inc.) also uses zotarolimus and the BioLinx polymer with a new CoCr strut design as noted earlier in an attempt to improve flexibility and deliverability without compromising radial strength. ${ }^{50,51}$ Clinical trials regarding these new platforms will be reviewed later in this paper.

\section{Everolimus-eluting stent}

Everolimus, another of the engineered lipophilic sirolimus analogs, has been incorporated into second-generation and third-generation DES. Everolimus binds to FKBP12 and interferes with a regulatory protein that controls cell metabolism and proliferation through inhibition of protein translation. ${ }^{52}$ It has a direct effect on vascular endothelium and has been shown to significantly reduce neointimal proliferation. ${ }^{41}$ Additionally, everolimus leads to selective clearing via autophagy of macrophages which are implicated in plaque destabilization, while only arresting proliferation of smooth muscle cells which helps to stabilize plaques. ${ }^{53}$ The larger pivotal trials involving the everolimus-eluting stent (EES) are summarized in Table 4 and Figure 3.

\section{EES versus bare metal stent and PES}

The first EES introduced into clinical practice was the Xience $\mathrm{V}$ (Abbott Vascular). Consisting of an $81 \mu \mathrm{m} \mathrm{CoCr}$ strut and PBMA primer layer followed by a biocompatible copolymer of polyvinylidene fluoride-co-hexafluoropropylene, it eluted approximately $80 \%$ of its everolimus in the first 30 days and $100 \%$ by 4 months. ${ }^{54}$ The SPIRIT FIRST (A Clinical Evaluation of an Investigational Device. The Abbott XIENCE $V^{\circledR}$

Table 4 EES outcomes in large trials

\begin{tabular}{|c|c|c|c|c|c|}
\hline Study & Endpoint & Time frame & Comparator & EES & $P$-value \\
\hline \multirow[t]{3}{*}{ SPIRIT IV ${ }^{60}$ (PES) } & TLF* & 12 months & $6.8 \%$ & $4.2 \%$ & 0.001 \\
\hline & TLR & 12 months & $4.6 \%$ & $2.5 \%$ & 0.001 \\
\hline & ST & 12 months & $1.1 \%$ & $0.3 \%$ & 0.004 \\
\hline \multirow[t]{3}{*}{ SORT OUT IV'77 (SES) } & $\begin{array}{l}\text { Composite* (cardiac death, } \\
\text { MI, definite ST, TVR) }\end{array}$ & 9 months & $5.2 \%$ & $4.9 \%$ & 0.71 \\
\hline & TLR & 9 months & $1.7 \%$ & $1.4 \%$ & 0.64 \\
\hline & ST & 9 months & $0.9 \%$ & $0.9 \%$ & 0.39 \\
\hline \multirow[t]{3}{*}{ RESOLUTE ALL COMERS ${ }^{68}$ (ZES) } & TLF* & 12 months & $8.2 \%$ & $8.3 \%$ & 0.94 \\
\hline & TLR & 12 months & $3.9 \%$ & $3.4 \%$ & 0.5 \\
\hline & ST & 12 months & $1.6 \%$ & $0.7 \%$ & 0.05 \\
\hline \multirow[t]{3}{*}{ TWENTE $^{70}$ (ZES) } & TVF* & 12 months & $8.2 \%$ & $8.1 \%$ & 0.001 \\
\hline & TLR & 12 months & $2.7 \%$ & $1.4 \%$ & 0.09 \\
\hline & ST & 12 months & $0.9 \%$ & $1.2 \%$ & 0.59 \\
\hline
\end{tabular}

Note: *Primary outcome.

Abbreviations: EES, everolimus-eluting stent; TLF, target lesion failure; TVR, target vessel revascularization; TLR, target lesion revascularization; ST, stent thrombosis; PES, paclitaxel-eluting stent; SES, sirolimus-eluting stent; ZES, zotarolimus-eluting stent. 


\section{Clinical TLR within 12 months vs EES}

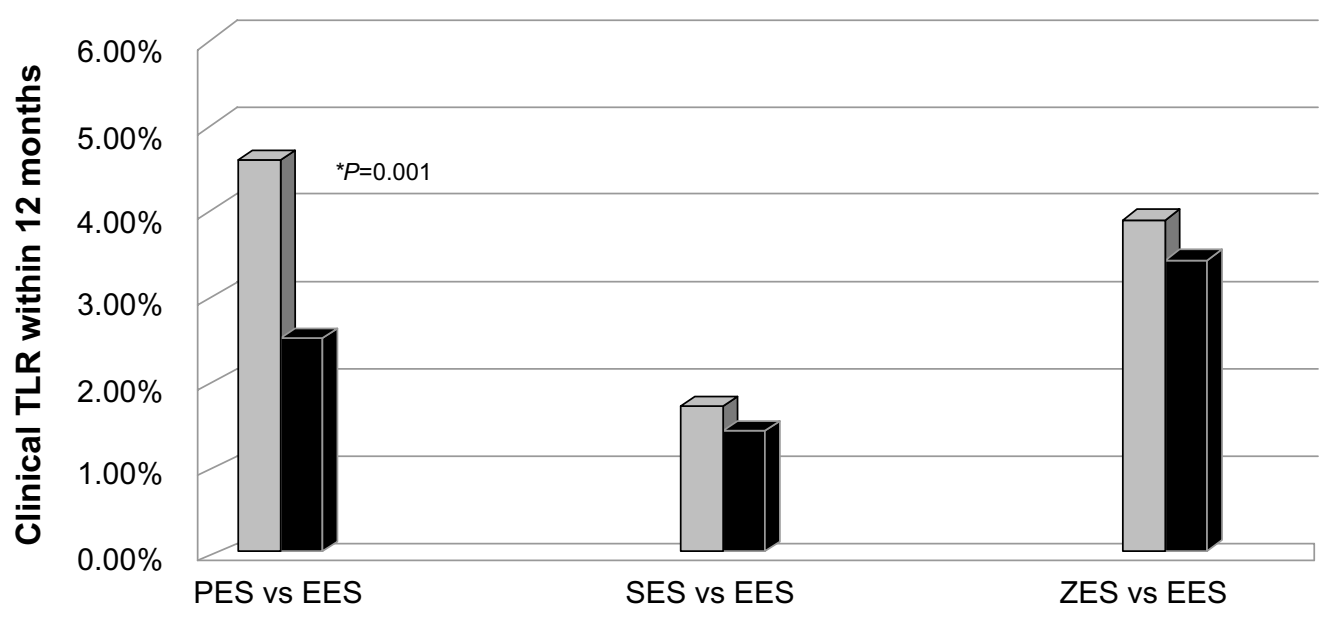

Figure 3 Trials of the everolimus-eluting stent (Spirit IV, SORT OUT IV, RESOLUTE ALL COMERS).

Notes: ${ }^{* P}<0.05$; data from Stone et al, ${ }^{60}$ Jensen et al, ${ }^{67}$ and Serryus et al..$^{68}$

Abbreviations: EES, everolimus-eluting stent; SES, sirolimus-eluting stent; PES, paclitaxel-eluting stent; ZES, zotarolimus-eluting stent; TLR, target lesion revascularization; vs, versus.

Everolimus Eluting Coronary Stent System in the Treatment of Patients With de Novo Native Coronary Artery Lesions) was the initial study of the Xience V platform comparing it against bare metal stents, and showed a greater than eight-fold increase in late lumen loss versus the EES $(0.87 \mathrm{~mm}$ versus $0.1 \mathrm{~mm}, P<0.001)$ at 6 months. ${ }^{55}$ The EXAMINATION (Everolimus-eluting stent versus bare metal stent in STelevation MI) trial demonstrated the improved safety and efficacy of the newer limus analogs in patients with STsegment elevation MI. At one year, rates for the combined primary endpoint (all-cause death, any MI, any revascularization) were similar. Target lesion and vessel revascularization significantly favored the EES, as did definite and probable stent thrombosis $(0.9 \%$ versus $2.5 \%, P=0.019) .{ }^{56}$

When compared with the PES in small trials (SPIRIT II and III), the EES showed a significant improvement in late lumen loss $(0.14 \mathrm{~mm}$ versus $0.28 \mathrm{~mm}, P \leq 0.004)$ at 8 months and was noninferior for target vessel failure (cardiac death, MI, target vessel revascularization) at 9-month clinical follow-up, with improved MACE (cardiac death, MI, target lesion revascularization) driven by target lesion revascularization. ${ }^{57,58}$ The MACE reduction remained significant at 2 years $(10.7 \%$ versus $15.4 \%$, $P=0.04)$, with no significant difference in stent thrombosis rates. ${ }^{59}$ The superiority and improved long-term safety was demonstrated in SPIRIT IV, a large-scale comparison of EES $(n=2,458)$ and PES $(n=1,229)$. SPIRIT IV showed superiority of the EES platform at one year, with a $38 \%$ relative risk reduction $(P=0.001)$ for target lesion failure (cardiac death, target vessel MI, target lesion revascularization). ${ }^{60}$ These results remained significant at 2 years, with decreased stent thrombosis $(0.4 \%$ versus $1.2 \%, P=0.008) .{ }^{61}$ A second large-scale real-world use trial, COMPARE (A Randomized Controlled Trial of Everolimus-eluting Stents and Paclitaxel-eluting Stents for Coronary Revascularization in Daily Practice), also showed superiority of the Xience V stent over the TAXUS Liberté PES platform for the composite primary endpoint (target vessel revascularization, all-cause death, and MI; $6 \%$ versus $9 \%, P=0.02$ ) at one year. ${ }^{62}$ Individual secondary endpoints of target lesion revascularization, MI, and cardiac death were all superior as well. Definite and probable stent thrombosis at 12 and 24 months $(0.9 \%$ versus $3.9 \%, P<0.001)$ were also significantly reduced with XIENCE V, as was very late stent thrombosis (more than one year; $0.3 \%$ versus $1.4 \%, P=0.01){ }^{62,63}$ From these data, it seemed clear that the EES platform had achieved a significant clinical improvement over the PES.

A pooled analysis of the 2-year follow-up of the SPIRIT and COMPARE trials evaluated differences in patients with acute coronary syndrome versus those with stable CAD. In patients with acute coronary syndrome, the EES demonstrated a significant reduction in death, MI, and clinical target lesion revascularization, and a $75 \%$ reduction in stent thrombosis ( $0.7 \%$ versus $2.9 \%, P=0.0002)$. Similar significant outcomes were noted in patients with stable CAD, favoring the EES. These results suggested that the EES platform is safe in all types of patients. ${ }^{64}$

\section{EES versus SES}

Fewer randomized studies have compared the EES with the SES. The randomized EXCELLENT (Efficacy of Xience/ Promus Versus Cypher to Reduce Late Loss After Stenting) 
trial showed 9-month noninferiority for late luminal loss with no difference in target lesion failure or stent thrombosis. ${ }^{65}$ In the BASKET-PROVE (BAsel Stent Kosten Effektivitäts Trial PROspective Validation Examination) study, SES and EES showed similar composite endpoints and stent thrombosis rates at 24 months. ${ }^{66}$ The SORT OUT IV trial showed noninferiority of the EES platform with regards to a composite clinical endpoint of safety (cardiac death, MI, and stent thrombosis) and efficacy, ie, target vessel revascularization (hazard ratio $0.94 ; 95 \% \mathrm{CI}[0.67-1.31], P=0.71) .{ }^{67}$ At 18 months, the EES continued to show noninferiority, with significantly lower rates of stent thrombosis $(0.2 \%$ versus $0.9 \%, P=0.02) .{ }^{67}$ These data suggest that the EES platform has improved safety and efficacy over the first-generation SES.

\section{EES versus ZES}

Several studies have compared the Xience V EES platform with the Endeavor Resolute ZES platform. In an early study, ie, RESOLUTE ALL COMERS (A Randomized Comparison of a Zotarolimus-Eluting Stent With an EverolimusEluting Stent for Percutaneous Coronary Intervention), Serruys et al found the Resolute to be noninferior to the EES for target lesion failure (cardiac death, target vessel MI, target lesion revascularization) at 12 months. ${ }^{68}$ However, the Resolute ZES had higher rates of definite stent thrombosis ( $1.2 \%$ versus $0.3 \%, P=0.01$ ). The noninferiority persisted after 2 years of follow-up with a trend towards higher definite and probable stent thrombosis $(1.9 \%$ versus $1.0 \%$, $P=0.08$ ) for the ZES platform. ${ }^{69}$ A second study, TWENTE (A Randomized Controlled Trial in the Second-Generation Zotarolimus-Eluting Resolute Stents Versus EverolimusEluting Xience V Stents in Real-World Patients), also directly compared the two stents, although in a smaller patient population, and found noninferiority between the two platforms at one-year and 2-year follow-up..$^{70,71}$ In this trial, there was no significant difference of definite or probable stent thrombosis at one year or for very late stent thrombosis (at more than one year). ${ }^{70}$ Several large registries support the findings of a lower rate of target vessel/lesion revascularization in favor of the EES. ${ }^{72,73}$ This comparison of similar generation stents is consistent with prior comparison studies suggesting that we should not expect iterative advances of the same generation to achieve large or significant improvements in overall MACE rates compared with each other. Therefore, some of these other measures of improved efficacy and safety become more relevant, such as less target lesion revascularization and less stent thrombosis, in head-to-head comparisons.

\section{Stent thrombosis with EES}

The incidence of definite and probable stent thrombosis (early, late, and very late) for the EES platform has been lower than with previous stent designs. A meta-analysis evaluated the randomized controlled trials to date comparing EES with other DES (SES, PES, and ZES) to further assess the safety of the EES platform with regard to stent thrombosis. At 2 years, the results favored the EES platform for definite stent thrombosis $(0.5 \%$ versus $1.3 \%, P<0.0001)$ and definite and probable stent thrombosis $(P<0.0001){ }^{74}$ The difference was significant for early stent thrombosis ( $\leq 30$ days) and persisted through late (30 days to one year) and very late (more than one year). Overall, these data suggest the CoCr EES platform offers improved efficacy and longterm safety over first-generation and other second-generation DES platforms.

\section{Third-generation platinum chromium DES}

As previously described, $\mathrm{PtCr}$ offers improved radial strength and density that allows for a smaller profile stent strut with excellent deliverability and significantly improved visibility. The Element platforms (Boston Scientific) utilize PtCr struts. The TAXUS Element is an $81 \mu \mathrm{m}$ PES and in PERSEUS (Prospective Evaluation in a Randomized Trial of the Safety and Efficacy of the Use of TAXUS Element Paclitaxel-Eluting Coronary Stent System) was found to be noninferior to the TAXUS Express (316L stainless steel PES) for target lesion revascularization and percent diameter stenosis at one year. ${ }^{19}$

The Promus Element utilizes everolimus and $\mathrm{PtCr}$. PLATINUM (A Prospective, Randomized, Multicenter Trial to Assess an Everolimus-Eluting Coronary Stent System [PROMUS Element] for the Treatment of up to Two De Novo Coronary Artery Lesions) compared the Promus Element (PtCr EES) with the Xience V (CoCr EES), and found the new Promus Element stent to be noninferior for target lesion failure (target vessel death or MI, or target lesion revascularization) as well as for stent thrombosis $(0.4 \%$ versus $0.4 \%$, $P=1.0$ ) at one year. ${ }^{20}$ At 2 years, each stent demonstrated comparable efficacy and safety, with stent thrombosis rates of $<1 \%$ for both platforms with signals toward decreased target lesion failure $(1.2 \%$ versus $3.0 \%, P=0.04)$ and target lesion revascularization $(0.7 \%$ versus $2.2 \%, P=0.02)$ with the PtCr stent. ${ }^{75}$

The Promus Element was compared with the Resolute Integrity in the DUTCH PEERS (Thirdgeneration zotarolimus-eluting and everolimus-eluting stents in all-comer patients requiring a percutaneous 
coronary intervention) study. This study showed noninferiority of the Resolute Integrity stent when compared with the Promus Element stent for target vessel failure (death, target vessel MI, and target vessel revascularization) at 12 months (6\% versus $5 \%, P=0.42) .{ }^{76}$ Stent thrombosis was again $<1 \%$ for both platforms.

\section{Next-generation technologies Polymer-free DES}

Since polymers have been implicated as a cause for late and very late stent thrombosis, stent design has also evaluated methods to eliminate polymers. The increased strength of the newer metal alloys has allowed for abluminal scoring and reservoirs to be made without affecting overall stent strength. ${ }^{28}$ Several similar designs utilizing different drugs have recently been tested against prior and current generation DES, and in early studies have demonstrated noninferiority with up to one-year follow-up. ${ }^{77-79}$ Some of the goals of these studies are to potentially reduce the length of use of dual antiplatelet therapy, late and very late stent thrombosis rates, and dose of antirestenosis drug needed, while maintaining current efficacy rates. The BioFreedom ${ }^{\mathrm{TM}}$ is a stainless steel strut with abluminal pores that elute most of its biolimus content over 28 days. In the BioFreedom first in man trial, this stent showed noninferiority with regard to late luminal loss (primary outcome) and MACE when compared with a TAXUS Liberté stent at 12 months. ${ }^{79} \mathrm{Cre} 8$ is a $\mathrm{CoCr}$ strut with abluminal reservoirs eluting most of its sirolimus within 28 days. The Cre8 study was a prospective randomized trial comparing the Cre8 with the TAXUS Liberté, and demonstrated a significant reduction in late loss at 6 months $(0.14 \pm 0.36 \mathrm{~mm}$ versus $0.34 \pm 0.40 \mathrm{~mm}, P<0.0001){ }^{78}$ The Demonstr8 (Randomized comparison between a DES and a BMS to assess neointimal coverage by OCT evaluation) study evaluated the Cre8 stent with only one month of dual antiplatelet therapy, measuring coverage of the Cre 8 stent by optical coherence tomography at 3 months compared with the Vision BMS at one month. The two stents were found to be noninferior in this regard, and there was a $56 \%$ reduction in neointima formation $(0.08 \mathrm{~mm} \pm 0.03$ versus $0.18 \mathrm{~mm} \pm 0.10$, $P<0.0001$ for superiority). ${ }^{80}$ These and other similar devices show promise in early studies, but long-term follow-up with studies designed to evaluate for individual endpoints of safety and efficacy will be needed.

\section{Bioabsorbable polymer coatings}

In as much as a durable polymer may impact long-term events, by delaying stent healing, contributing to neointimal hyperplasia and stent thrombosis, efforts have logically focused on developing nondurable (bioabsorbable) polymers such as PGA and PLA. Several bioabsorbable polymer stents, in which the polymers are absorbed within 6-12 months, are currently being evaluated for safety and efficacy. There are over a dozen platforms currently, with different base metals and novel polymers utilizing sirolimus, paclitaxel, biolimus, and everolimus as their drug (Table 5). Some of the larger clinical trials regarding these stents are reviewed here.

The Excel (JW Medical Systems, Weihai, People's Republic of China) stent design includes 316L stainless steel struts, a PLA polymer, and sirolimus. CREATE (Multi-Center Registry of EXCEL Biodegradable Polymer Drug Eluting Stents) was a nonrandomized, multicenter, prospective study with 5-year follow-up data on 1,982 patients using the Excel platform and found the overall MACE rate (cardiac death, nonfatal $\mathrm{MI}$, target lesion revascularization) to be $7.4 \%$. There was a $1.1 \%$ rate of definite or probable stent thrombosis at 5 years, with a rate of definite stent thrombosis from years 1 to 5 (very late stent thrombosis) of $0.3 \% .{ }^{81}$ When patients who stopped clopidogrel after 6 months $(n=1,626)$ were compared with those who continued clopidogrel after 6 months $(\mathrm{n}=408)$, there was no difference in MACE $(5.8 \%$ versus $7.4 \%, P=0.256)$ or stent thrombosis $(0.6 \%$ versus $0.5 \%, P=1.0$ ) rates. ${ }^{81}$ With the promise of reduced need for dual antiplatelet therapy, further study is needed to evaluate the effectiveness of this stent design in comparison with current DES.

The BioMatrix stent (Biosensors Inc., Newport Beach, CA, USA) utilizes a 316L stainless steel strut, biolimus, and a biodegradable PLA polymer that is only administered to the abluminal surface of the stent. LEADERS (the Biolimuseluting stent with a biodegradable polymer versus the SES with a durable polymer for coronary revascularization trial) was a randomized noninferiority trial. At the 9-month follow-up, the composite endpoint of death, MI, or target vessel revascularization demonstrated noninferiority $(9 \%$ versus $11 \%$, relative risk $0.88,95 \%$ CI $0.64-1.19, P=0.003$ for noninferiority).$^{82}$ The noninferiority persisted at 4 years, with event rates of $18.7 \%$ for the biolimus-eluting stent (BES) versus $22.6 \%$ for the SES (relative risk $0.81,95 \% \mathrm{CI}$ $0.66-1.0, P<0.0001$ for noninferiority) and was just short of showing superiority ( $P=0.05$ for superiority) ${ }^{83}$ Definite very late stent thrombosis rates were improved with the BES (relative risk $0.20,95 \%$ CI $0.06-0.67, P=0.004) .{ }^{83}$ With long-term follow-up, the biodegradable BioMatrix BES has demonstrated good efficacy with improved safety. 
Table 5 Bioabsorbable stent characteristics

\begin{tabular}{|c|c|c|c|c|c|c|c|c|}
\hline Type & Drug & $\begin{array}{l}\text { Stent } \\
\text { name }\end{array}$ & Stent base & $\begin{array}{l}\text { Strut } \\
\text { thickness } \\
(\mu \mathrm{m})\end{array}$ & Polymer & Abluminal & $\begin{array}{l}\text { Polymer } \\
\text { duration }\end{array}$ & Manufacturer \\
\hline \multicolumn{9}{|c|}{ Polymer } \\
\hline & Sirolimus & Excel & $316 \mathrm{~L} \mathrm{SS}$ & 120 & PLA & Yes & 9 months & JW Medical \\
\hline & & & & & & & & Systems \\
\hline & & NOYA & $\mathrm{L} 605 \mathrm{CoCr}$ & 81 & PDLLA & & 4 months & Medfavour Medical \\
\hline & & Supralimus & $316 \mathrm{LSS}$ & 80 & PLLA & No & 7 months & Sahajanand Medical \\
\hline & & & & & & & & Technologies \\
\hline & & & & & PDLLGA & & & \\
\hline & & & & & PVP & & & \\
\hline & & Supralimus & $\mathrm{L} 605 \mathrm{CoCr}$ & 55.9 & PLLA & No & 7 months & Sahajanand Medical \\
\hline & & core & & & & & & Technologies \\
\hline & & & & & PDLLGA & & & \\
\hline & & & & & PVP & & & \\
\hline & & Cura & $316 \mathrm{~L} \mathrm{SS}$ & 100 & PLA + PLGA & Yes & 7 weeks & OrbusNeich \\
\hline & & Tivoli & $\mathrm{CoCr}$ & 80 & PLGA & & 6 months & Essen Technology \\
\hline & & Firehawk $^{\circledR}$ & $\mathrm{L} 605 \mathrm{CoCr}$ & 86 & PLA & Yes & & MicroPort Medical \\
\hline & & & & & & Abluminal & & \\
\hline & & & & & & grooves + entire & & \\
\hline & & & & & & stent coated & & \\
\hline & Paclitaxel & Infinnium & $316 \mathrm{LSS}$ & 80 & PLLA & No & 7 months & Sahajanand Medical \\
\hline & & & & & & & & Technologies \\
\hline & & & & & PDLLGA & & & \\
\hline & & & & & PVP & & & \\
\hline & & JACTAX HD & $316 \mathrm{LSS}$ & 38 & PLA & Yes & 4 months & Boston Scientific \\
\hline & & Luc Chopin & $316 \mathrm{~L} \mathrm{SS}$ & 120 & $\mathrm{PLA}+\mathrm{PGA}$ & No & 8 weeks & Balton \\
\hline & Biolimus & BioMatrix & $316 \mathrm{~L} \mathrm{SS}$ & 120 & PLA & Yes & 9 months & Biosensors \\
\hline & & & & & & & & International \\
\hline & & Nobori & $316 \mathrm{LSS}$ & 120 & PLA & Yes & 8 months & Terumo \\
\hline & Everolimus & Synergy & $\mathrm{PtCr}$ & 74 & PLGA & Yes & 4 months & Boston Scientific \\
\hline \multicolumn{9}{|l|}{ Strut } \\
\hline & None & AMS & Magnesium & 165 & & & 4 months & Biotronik \\
\hline & & REVA & Tyrosine-derived & 200 & & & 2 years & REVA Medical \\
\hline & & & polycarbonate & & & & & \\
\hline & & & polymer & & & & & \\
\hline & Everolimus & BVS & PLLA & 150 & PDLLA & No & 30 days drug; & Abbott Vascular \\
\hline & & & & & & & 24 months & \\
\hline & & & & & & & scaffold & \\
\hline
\end{tabular}

Abbreviations: AMS, absorbable metal stent; BVS, bioresorbable vascular scaffold; CoCr, cobalt chromium; SS, stainless steel; PLA, polylactic acid; PDLLA, poly-DL-lactide; PLLA, poly-L-lactide; PDLLGA, poly DL-lactide-co-glycolide; PVP, polyvinyl pyrrolidone; PLGA, polylactic acid/polyglycolic acid; PtCr, platinum chromium.

There still remains some concern regarding the higher rates of late stent thrombosis seen with use of the firstgeneration DES in patients with ST-segment elevation MI. As previously reported in this paper, the data suggest that the new agent, everolimus (second-generation and thirdgeneration) has shown improved rates of stent thrombosis. The BioMatrix stent was studied in the special population of patients with ST-segment elevation MI in the COMFORTABLE-AMI (Effect of Biolimus-Eluting stents with Biodegradable Polymer versus Bare Metal Stents on Cardiovascular Events Among Patients with Acute Myocardial Infarction) trial. MACE (cardiac death, target vessel MI, target lesion revascularization) at 12 months favored the BES (4.3\% versus $8.7 \%$, hazards ratio 0.49 , $95 \%$ CI [0.30-0.80], $P=0.004) .{ }^{84}$ Definite or probable stent thrombosis rates were no different at one year. This study, along with the previously mentioned data, suggests that the newer limus analogs will be safe in patients with acute coronary syndrome. Long-term follow-up will show if biolimus can reduce very late stent thrombosis rates.

The Nobori ${ }^{\circledR}$ stent (Terumo Corporation, Tokyo, Japan) is another BES that uses 316L stainless steel and the abluminal PLA polymer. SORT OUT V compared the Nobori BES with the Cypher SES, but interestingly found the BES to be inferior to the SES at 9 months for composite cardiac death, MI, and definite stent thrombosis (4.1\% BES versus 
$3.1 \%$ SES, $P=0.06),{ }^{85}$ unlike the BioMatrix data reported in the bioabsorbable polymer coatings section. This was driven by acute and subacute ( $<30$ days) stent thrombosis. ${ }^{85}$ In the COMPARE II (Abluminal biodegradable polymer biolimuseluting stent versus durable polymer everolimus-eluting stent) study, the Nobori was found to be noninferior to the Xience platform at 12 months for the composite endpoint of cardiac death, MI, and target vessel revascularization. ${ }^{86}$ Use of a nonallocated stent was higher with the Nobori $(5.8 \%$ versus $2.1 \%, P<0.0001$ ) due to limited size availability and failure to cross the lesion. Stent thrombosis was similar at one year, and long-term follow-up will be needed. The different endpoints used in the different BES studies make direct comparisons difficult, and larger-scale studies are needed to better understand individual outcomes, as well as long-term safety. Further, the clinical differences between the BioMatrix and Nobori platforms will need to be better understood to help further refine the stent design process for those stents.

The Synergy stent (Boston Scientific) utilizes a PtCr stent strut with an abluminal bioabsorbable polymer (polylactic acid/polyglycolic acid) and everolimus. Polymer absorption should be complete by 4 months. The EVOLVE (A Randomized Evaluation of a Novel Bioabsorbable Polymer-Coated, Everolimus-Eluting Coronary Stent) trial sought to compare the Synergy stent with the Promus Element (PtCr EES) stent at two doses of everolimus (same dose as the Promus Element stent and at half the dose) ${ }^{87}$ At 30 days, there was no significant difference in target lesion failure (death, target vessel MI, target lesion revascularization); however, the absolute differences of $0 \%$ (Element), 1\% (Synergy full dose), and $3.1 \%$ (Synergy half dose) were entirely driven by target vessel MI. ${ }^{87}$ When 2-year follow-up data were reviewed, there was again no difference in target lesion failure between the groups, ie, 6.1\% (Element), 5.5\% (Synergy), and 5.2\% (Synergy half dose). ${ }^{88}$ Interestingly, there was more target lesion revascularization in the Element stent group and more target vessel MI and death in the Synergy stent group, that led to equalization of absolute event rates. Large-scale studies, such as EVOLVE II, are required.

\section{Bioabsorbable struts}

The BVS stent (Abbott Vascular) strut scaffold is constructed of the PLLA polymer that is absorbed by 18-24 months and a second polymer coating of poly-D,L-lactide that elutes everolimus over 30 days. In the ABSORB (A bioabsorbable everolimus-eluting coronary stent system for patients with single de-novo coronary artery lesions) study, an initial safety trial of 30 patients showed a MACE rate of $3.3 \%$ which was solely one non-Q wave MI at one year, ${ }^{89}$ and at 4 years remained at $3.4 \%$ with no new clinical events. ${ }^{90}$ The ABSORB II trial will compare the second-generation BVS with the Xience $\mathrm{V}$ in approximately 501 patients across Europe and New Zealand, with a planned 3-year follow-up. ${ }^{91}$ ABSORB III will also compare the BVS with the Xience V, enrolling approximately 2,250 patients, mostly within the USA, with up to 5 years of planned follow-up. Results from these trials are pending.

\section{Conclusion}

The introduction of intracoronary stents represented a major breakthrough in interventional cardiology, and numerous advances have dramatically enhanced the deliverability, safety, and efficacy of these stents over the past two decades. Bare metal stents set the benchmark for improved safety over angioplasty, and the first-generation DES was a significant advance in efficacy, but not necessarily safety. Second-generation and third-generation stents represent advances in performance in terms of enhanced delivery and improved radial strength, as well as efficacy and safety via decreased late loss and a lower risk of stent thrombosis. Current advances and understanding of stent design continue to improve on these concepts, and the current standards outperform earlier designs in all facets. The next frontier includes polymer-free stents or platforms with some degree of bioabsorbability, whether merely the polymer or the entire stent. Randomized studies evaluating many of these products are ongoing, and the results of these trials will most definitely advance our understanding and fuel further innovation.

\section{Disclosure}

DHS has been a consultant to and/or received honoraria from Terumo Interventional Systems, Boston Scientific, St Jude Medical, and Astra Zeneca. The other authors report no conflicts of interest in this work.

\section{References}

1. Kent KM, Bentivoglio LG, Block PC, et al. Percutaneous transluminal coronary angioplasty: report from the Registry of the National Heart, Lung, and Blood Institute. Am J Cardiol. 1982;49(8):2011-2020.

2. Chamberlain DA, Fox KAA, Henderson RA, Julian DG, Parker DJ, Pocock SJ. Coronary angioplasty versus medical therapy for angina: the second Randomised Intervention Treatment of Angina (RITA-2) trial. RITA-2 trial participants. Lancet. 1997;350(9076):461-468.

3. Parisi AF, Folland ED, Hartigan P. A comparison of angioplasty with medical therapy in the treatment of single-vessel coronary artery disease. Veterans Affairs ACME Investigators. N Engl J Med. 1992;326(1):10-16.

4. Fischman DL, Leon MB, Baim DS, et al. A randomized comparison of coronary-stent placement and balloon angioplasty in the treatment of coronary artery disease. Stent Restenosis Study Investigators. $N$ Engl $J$ Med. 1994;331(8):496-501. 
5. Serruys PW, de Jaegere P, Kiemeneij F, et al. A comparison of balloonexpandable-stent implantation with balloon angioplasty in patients with coronary artery disease. Benestent Study Group. $N$ Engl J Med. 1994;331(8):489-495.

6. Lemos PA, Serruys PW, van Domburg RT, et al. Unrestricted utilization of sirolimus-eluting stents compared with conventional bare stent implantation in the "real world": the Rapamycin-Eluting Stent Evaluated At Rotterdam Cardiology Hospital (RESEARCH) registry. Circulation. 2004;109(2):190-195.

7. Moses JW, Leon MB, Popma JJ, et al. Sirolimus-eluting stents versus standard stents in patients with stenosis in a native coronary artery. N Engl J Med. 2003;349(14):1315-1323.

8. Stone GW, Ellis SG, Cox DA, et al. A polymer-based, paclitaxeleluting stent in patients with coronary artery disease. $N$ Engl J Med. 2004;350(3):221-231.

9. Lagerqvist B, James SK, Stenestrand U, Lindback J, Nilsson T, Wallentin L. Long-term outcomes with drug-eluting stents versus baremetal stents in Sweden. N Engl J Med. 2007;356(10):1009-1019.

10. Stone GW, Moses JW, Ellis SG, et al. Safety and efficacy of sirolimusand paclitaxel-eluting coronary stents. $N$ Engl J Med. 2007;356(10): 998-1008.

11. Mani G, Feldman MD, Patel D, Agrawal CM. Coronary stents: a materials perspective. Biomaterials. 2007;28(9):1689-1710

12. Kastrati A, Mehilli J, Dirschinger J, et al. Intracoronary stenting and angiographic results: strut thickness effect on restenosis outcome (ISAR-STEREO) trial. Circulation. 2001;103(23):2816-2821.

13. Pache J, Kastrati A, Mehilli J, et al. Intracoronary stenting and angiographic results: strut thickness effect on restenosis outcome (ISARSTEREO-2) trial. J Am Coll Cardiol. 2003;41(8):1283-1288.

14. Rittersma SZ, de Winter RJ, Koch KT, et al. Impact of strut thickness on late luminal loss after coronary artery stent placement. Am J Cardiol. 2004;93(4):477-480.

15. Kereiakes DJ, Cox DA, Hermiller JB, et al. Usefulness of a cobalt chromium coronary stent alloy. Am J Cardiol. 2003;92(4): 463-466.

16. O'Brien BJ, Stinson JS, Larsen SR, Eppihimer MJ, Carroll WM. A platinum-chromium steel for cardiovascular stents. Biomaterials. 2010;31(14):3755-3761.

17. Menown IB, Noad R, Garcia EJ, Meredith I. The platinum chromium element stent platform: from alloy, to design, to clinical practice. $A d v$ Ther. 2010;27(3):129-141.

18. Turco MA. The Integrity bare-metal stent made by continuous sinusoid technology. Expert Rev Med Devices. 2011;8(3):303-306.

19. Kereiakes DJ, Cannon LA, Feldman RL, et al. Clinical and angiographic outcomes after treatment of de novo coronary stenoses with a novel platinum chromium thin-strut stent: primary results of the PERSEUS (Prospective Evaluation in a Randomized Trial of the Safety and Efficacy of the Use of the TAXUS Element PaclitaxelEluting Coronary Stent System) trial. J Am Coll Cardiol. 2010;56(4): 264-271.

20. Stone GW, Teirstein PS, Meredith IT, et al. A prospective, randomized evaluation of a novel everolimus-eluting coronary stent: the PLATINUM (a Prospective, Randomized, Multicenter Trial to Assess an Everolimus-Eluting Coronary Stent System [PROMUS Element] for the Treatment of Up to Two de Novo Coronary Artery Lesions) trial. J Am Coll Cardiol. 2011;57(16):1700-1708.

21. Mortier P, De Beule M. Stent design back in the picture: an engineering perspective on longitudinal stent compression. EuroIntervention. 2011;7(7):773, 775 .

22. Ormiston JA, Webber B, Webster MW. Stent longitudinal integrity bench insights into a clinical problem. JACC Cardiovasc Interv. 2011;4(12):1310-1317.

23. Ormiston J. Clinical, angiographic and IVUS outcomes of the NG PROMUS clinical trial evaluating the novel Promus Premier stent. Paper presented at the EuroPCR meeting, May 21-24, 2013, Paris, France.
24. Nishio S, Kosuga K, Igaki K, et al. Long-term ( $>10$ years) clinical outcomes of first-in-human biodegradable poly-1-lactic acid coronary stents: Igaki-Tamai stents. Circulation. 2012;125(19):2343-2353.

25. Tamai H, Igaki K, Kyo E, et al. Initial and 6-month results of biodegradable poly-l-lactic acid coronary stents in humans. Circulation. 2000;102(4):399-404.

26. Ormiston JA, Serruys PW. Bioabsorbable coronary stents. Circ Cardiovasc Interv. 2009;2(3):255-260.

27. Pendyala L, Jabara R, Robinson K, Chronos N. Passive and active polymer coatings for intracoronary stents: novel devices to promote arterial healing. $J$ Interv Cardiol. 2009;22(1):37-48.

28. O'Brien B, Carroll W. The evolution of cardiovascular stent materials and surfaces in response to clinical drivers: a review. Acta Biomater. 2009;5(4):945-958.

29. Nebeker JR, Virmani R, Bennett CL, et al. Hypersensitivity cases associated with drug-eluting coronary stents: a review of available cases from the Research on Adverse Drug Events and Reports (RADAR) project. J Am Coll Cardiol. 2006;47(1):175-181.

30. Virmani R, Guagliumi G, Farb A, et al. Localized hypersensitivity and late coronary thrombosis secondary to a sirolimus-eluting stent: should we be cautious? Circulation. 2004;109(6):701-705.

31. Joner M, Finn AV, Farb A, et al. Pathology of drug-eluting stents in humans: delayed healing and late thrombotic risk. J Am Coll Cardiol. 2006;48(1):193-202.

32. van der Giessen WJ, Lincoff AM, Schwartz RS, et al. Marked inflammatory sequelae to implantation of biodegradable and nonbiodegradable polymers in porcine coronary arteries. Circulation. 1996;94(7):1690-1697.

33. Lewis AL, Tolhurst LA, Stratford PW. Analysis of a phosphorylcholinebased polymer coating on a coronary stent pre- and post-implantation. Biomaterials. 2002;23(7):1697-1706.

34. Fajadet J, Wijns W, Laarman GJ, et al. Randomized, double-blind, multicenter study of the Endeavor zotarolimus-eluting phosphorylcholine-encapsulated stent for treatment of native coronary artery lesions: clinical and angiographic results of the ENDEAVOR II trial. Circulation. 2006;114(8):798-806.

35. Guagliumi G, Ikejima H, Sirbu V, et al. Impact of drug release kinetics on vascular response to different zotarolimus-eluting stents implanted in patients with long coronary stenoses: the LongOCT study (Optical Coherence Tomography in Long Lesions). JACC Cardiovasc Interv. 2011;4(7):778-785.

36. Morice MC, Serruys PW, Sousa JE, et al. A randomized comparison of a sirolimus-eluting stent with a standard stent for coronary revascularization. $N$ Engl J Med. 2002;346(23):1773-1780.

37. Heldman AW, Cheng L, Jenkins GM, et al. Paclitaxel stent coating inhibits neointimal hyperplasia at 4 weeks in a porcine model of coronary restenosis. Circulation. 2001;103(18):2289-2295.

38. Finn AV, Nakazawa G, Joner M, et al. Vascular responses to drug eluting stents: importance of delayed healing. Arterioscler Thromb Vasc Biol. 2007;27(7):1500-1510.

39. Burke SE, Kuntz RE, Schwartz LB. Zotarolimus (ABT-578) eluting stents. Adv Drug Deliv Rev. 2006;58(3):437-446.

40. Claessen BE, Henriques JP, Dangas GD. Clinical studies with sirolimus, zotarolimus, everolimus, and biolimus A9 drug-eluting stent systems. Curr Pharm Des. 2010;16(36):4012-4024.

41. Waksman R, Pakala R, Baffour R, et al. Optimal dosing and duration of oral everolimus to inhibit in-stent neointimal growth in rabbit iliac arteries. Cardiovasc Revasc Med. 2006;7(3):179-184.

42. Fajadet J, Wijns W, Laarman GJ, et al. Long-term follow-up of the randomised controlled trial to evaluate the safety and efficacy of the zotarolimus-eluting driver coronary stent in de novo native coronary artery lesions: five year outcomes in the ENDEAVOR II study. EuroIntervention. 2010;6(5):562-567.

43. Leon MB, Mauri L, Popma JJ, et al. A randomized comparison of the Endeavor zotarolimus-eluting stent versus the TAXUS paclitaxel-eluting stent in de novo native coronary lesions 12-month outcomes from the ENDEAVOR IV trial. J Am Coll Cardiol. 2010;55(6):543-554. 
44. Leon MB, Nikolsky E, Cutlip DE, et al. Improved late clinical safety with zotarolimus-eluting stents compared with paclitaxel-eluting stents in patients with de novo coronary lesions: 3-year follow-up from the ENDEAVOR IV (Randomized Comparison of Zotarolimus- and Paclitaxel-Eluting Stents in Patients With Coronary Artery Disease) trial. JACC Cardiovasc Interv. 2010;3(10):1043-1050.

45. Kandzari DE, Leon MB, Popma JJ, et al. Comparison of zotarolimuseluting and sirolimus-eluting stents in patients with native coronary artery disease: a randomized controlled trial. J Am Coll Cardiol. 2006;48(12):2440-2447.

46. Rasmussen K, Maeng M, Kaltoft A, et al. Efficacy and safety of zotarolimus-eluting and sirolimus-eluting coronary stents in routine clinical care (SORT OUT III): a randomised controlled superiority trial. Lancet. 2010;375(9720):1090-1099.

47. Maeng M, Tilsted HH, Jensen LO, et al. 3-Year clinical outcomes in the randomized SORT OUT III superiority trial comparing zotarolimusand sirolimus-eluting coronary stents. JACC Cardiovasc Interv. 2012;5(8):812-818.

48. Kandzari DE, Mauri L, Popma JJ, et al. Late-term clinical outcomes with zotarolimus- and sirolimus-eluting stents. 5-year follow-up of the ENDEAVOR III (A Randomized Controlled Trial of the Medtronic Endeavor Drug [ABT-578] Eluting Coronary Stent System Versus the Cypher Sirolimus-Eluting Coronary Stent System in De Novo Native Coronary Artery Lesions). JACC Cardiovasc Interv. 2011;4(5):543-550.

49. Brugaletta S, Burzotta F, Sabate M. Zotarolimus for the treatment of coronary artery disease: pathophysiology, DES design, clinical evaluation and future perspective. Expert Opin Pharmacother. 2009;10(6):1047-1058.

50. Banerjee $\mathrm{S}$. The Resolute Integrity zotarolimus-eluting stent in coronary artery disease: a review. Cardiology and Therapy. 2013;2(1):9.

51. Belardi JA, Albertal M. Integrity(R) coronary stent: a very limber baremetal stent. Catheter Cardiovasc Interv. 2011;78(6):909.

52. Bennett J, Dubois C. A novel platinum chromium everolimuseluting stent for the treatment of coronary artery disease. Biologics. 2013;7:149-159.

53. Verheye S, Martinet W, Kockx MM, et al. Selective clearance of macrophages in atherosclerotic plaques by autophagy. J Am Coll Cardiol. 2007;49(6):706-715.

54. Ding N, Pacetti S, Tang F-W, Gada M, Roorda W. Xience V stent design and rationale. J Interv Cardiol. 2009;22(s1):s18-s27.

55. Serruys PW, Ong AT, Piek JJ, et al. A randomized comparison of a durable polymer Everolimus-eluting stent with a bare metal coronary stent: the SPIRIT first trial. EuroIntervention. 2005;1(1):58-65.

56. Sabate M, Cequier A, Iniguez A, et al. Everolimus-eluting stent versus bare-metal stent in ST-segment elevation myocardial infarction (EXAMINATION): 1 year results of a randomised controlled trial. Lancet. 2012;380(9852):1482-1490.

57. Serruys PW, Ruygrok P, Neuzner J, et al. A randomised comparison of an everolimus-eluting coronary stent with a paclitaxel-eluting coronary stent: the SPIRIT II trial. Euro Intervention. 2006;2(3):286-294.

58. Stone GW, Midei M, Newman W, et al. Comparison of an everolimuseluting stent and a paclitaxel-eluting stent in patients with coronary artery disease: a randomized trial. JAMA. 2008;299(16):1903-1913.

59. Stone GW, Midei M, Newman W, et al. Randomized comparison of everolimus-eluting and paclitaxel-eluting stents: two-year clinical follow-up from the Clinical Evaluation of the Xience V Everolimus Eluting Coronary Stent System in the Treatment of Patients with de novo Native Coronary Artery Lesions (SPIRIT) III trial. Circulation. 2009;119(5):680-686.

60. Stone GW, Rizvi A, Newman W, et al. Everolimus-eluting versus paclitaxel-eluting stents in coronary artery disease. $N$ Engl $\mathrm{J} \mathrm{Med}$. 2010;362(18):1663-1674.

61. Stone GW, Rizvi A, Sudhir K, et al. Randomized comparison of everolimus- and paclitaxel-eluting stents. 2-year follow-up from the SPIRIT (Clinical Evaluation of the XIENCE V Everolimus Eluting Coronary Stent System) IV trial. J Am Coll Cardiol. 2011;58(1):19-25.
62. Kedhi E, Joesoef KS, McFadden E, et al. Second-generation everolimuseluting and paclitaxel-eluting stents in real-life practice (COMPARE): a randomised trial. Lancet. 2010;375(9710):201-209.

63. Smits PC, Kedhi E, Royaards KJ, et al. 2-year follow-up of a randomized controlled trial of everolimus- and paclitaxel-eluting stents for coronary revascularization in daily practice. COMPARE (Comparison of the everolimus eluting XIENCE-V stent with the paclitaxel eluting TAXUS LIBERTE stent in all-comers: a randomized open label trial). J Am Coll Cardiol. 2011;58(1):11-18.

64. Planer D, Smits PC, Kereiakes DJ, et al. Comparison of everolimusand paclitaxel-eluting stents in patients with acute and stable coronary syndromes: pooled results from the SPIRIT (A Clinical Evaluation of the XIENCE V Everolimus Eluting Coronary Stent System) and COMPARE (A Trial of Everolimus-Eluting Stents and PaclitaxelEluting Stents for Coronary Revascularization in Daily Practice) Trials JACC Cardiovasc Interv. 2011;4(10):1104-1115.

65. Park KW, Chae IH, Lim DS, et al. Everolimus-eluting versus sirolimuseluting stents in patients undergoing percutaneous coronary intervention: the EXCELLENT (Efficacy of Xience/Promus Versus Cypher to Reduce Late Loss After Stenting) randomized trial. J Am Coll Cardiol. 2011;58(18):1844-1854.

66. Kaiser C, Galatius S, Erne P, et al. Drug-eluting versus bare-metal stents in large coronary arteries. N Engl J Med. 2010;363(24): 2310-2319.

67. Jensen LO, Thayssen P, Hansen HS, et al. Randomized comparison of everolimus-eluting and sirolimus-eluting stents in patients treated with percutaneous coronary intervention: the Scandinavian Organization for Randomized Trials with Clinical Outcome IV (SORT OUT IV). Circulation. 2012;125(10):1246-1255.

68. Serruys PW, Silber S, Garg S, et al. Comparison of zotarolimus-eluting and everolimus-eluting coronary stents. $N$ Engl J Med. 2010;363(2): 136-146.

69. Silber S, Windecker S, Vranckx P, Serruys PW, investigators RAC. Unrestricted randomised use of two new generation drug-eluting coronary stents: 2-year patient-related versus stent-related outcomes from the RESOLUTE All Comers trial. Lancet. 2011;377(9773): 1241-1247.

70. Tandjung K, Sen H, Lam MK, et al. Clinical outcome following stringent discontinuation of dual antiplatelet therapy after 12 months in real-world patients treated with second-generation zotarolimus-eluting resolute and everolimus-eluting Xience V stents: 2-year follow-up of the randomized TWENTE trial. J Am Coll Cardiol. 2013;61(24): 2406-2416.

71. von Birgelen C, Basalus MW, Tandjung K, et al. A randomized controlled trial in second-generation zotarolimus-eluting Resolute stents versus everolimus-eluting Xience V stents in real-world patients: the TWENTE trial. J Am Coll Cardiol. 2012;59(15): 1350-1361.

72. Damman P, Abdel-Wahab M, Mollmann H, et al. Comparison of twelve-month outcomes after percutanous coronary intervention with everolimus-eluting versus zotarolimus-eluting or sirolimus-eluting stents from the PROENCY (PROmus ENdeavor CYpher) registry. J Invasive Cardiol. 2012;24(10):495-502.

73. Park KW, Lee JM, Kang SH, et al. Safety and efficacy of second-generation everolimus-eluting Xience $\mathrm{V}$ stents versus zotarolimus-eluting resolute stents in real-world practice: patient-related and stent-related outcomes from the multicenter prospective EXCELLENT and RESOLUTE-Korea registries. J Am Coll Cardiol. 2013;61(5):536-544.

74. Palmerini T, Kirtane AJ, Serruys PW, et al. Stent thrombosis with everolimus-eluting stents: meta-analysis of comparative randomized controlled trials. Circ Cardiovasc Interv. 2012;5(3):357-364.

75. Boston Scientific. Landmark analysis of year two data from PLATINUM Workhorse Trial demonstrates superior efficacy of PROMUS Element platinum chromium stent compared with Promus (Xience V) Stent. 2012. Available from: http://bostonscientific.mediaroom.com/index. php?s=24889\&item=125347. Accessed November 12, 2013. 
76. von Birgelen C, Sen H, Lam MK, et al. Third-generation zotarolimuseluting and everolimus-eluting stents in all-comer patients requiring a percutaneous coronary intervention (DUTCH PEERS): a randomised, single-blind, multicentre, non-inferiority trial. Lancet. 2014;383(9915): 413-423.

77. Byrne RA, Mehilli J, Iijima R, et al. A polymer-free dual drugeluting stent in patients with coronary artery disease: a randomized trial versus polymer-based drug-eluting stents. Eur Heart J. 2009;30(8):923-931.

78. Carrie D. NEXT A prospective, randomized trial comparing Cre8, a polymer-free stent eluting sirolimus, to a paclitaxel-eluting stent. Paper presented at the Transcatheter Cardiovascular Therapeutics 23rd Annual Scientific Symposium, November 7-11, 2011, San Francisco, CA, USA.

79. Grube E. BIOFREEDOM: a prospective randomized trial of polymerfree bioliums a9-eluting stents and paclitaxel-eluting stents in patients with coronary artery disease. Paper presented at at the Transcatheter Cardiovascular Therapeutics 22rd Annual Scientific Symposium, September 23-25, 2010, Washington, DC, USA.

80. Stella PR. Demonstr8 randomized trial results: Cre8: reduced antiplatelet therapy with effective DES. Paper presented at the EuroPCR meeting, May 21-24, 2013, Paris, France.

81. Han YL, Zhang L, Yang LX, et al. A new generation of biodegradable polymer-coated sirolimus-eluting stents for the treatment of coronary artery disease: final 5-year clinical outcomes from the CREATE study. EuroIntervention. 2012;8(7):815-822.

82. Windecker S, Serruys PW, Wandel S, et al. Biolimus-eluting stent with biodegradable polymer versus sirolimus-eluting stent with durable polymer for coronary revascularisation (LEADERS): a randomised non-inferiority trial. Lancet. 2008;372(9644):1163-1173.

83. Stefanini GG, Kalesan B, Serruys PW, et al. Long-term clinical outcomes of biodegradable polymer biolimus-eluting stents versus durable polymer sirolimus-eluting stents in patients with coronary artery disease (LEADERS): 4 year follow-up of a randomised non-inferiority trial. Lancet. 2011;378(9807):1940-1948.

84. Raber L, Kelbaek H, Ostojic M, et al. Effect of biolimus-eluting stents with biodegradable polymer vs bare-metal stents on cardiovascular events among patients with acute myocardial infarction: the COMFORTABLE AMI randomized trial. JAMA. 2012;308(8): $777-787$.
85. Christiansen EH, Jensen LO, Thayssen P, et al. Biolimus-eluting biodegradable polymer-coated stent versus durable polymer-coated sirolimus-eluting stent in unselected patients receiving percutaneous coronary intervention (SORT OUT V): a randomised non-inferiority trial. Lancet. 2013;381(9867):661-669.

86. Smits PC, Hofma S, Togni M, et al. Abluminal biodegradable polymer biolimus-eluting stent versus durable polymer everolimus-eluting stent (COMPARE II): a randomised, controlled, non-inferiority trial. Lancet. 2013;381(9867):651-660.

87. Meredith IT, Verheye S, Dubois CL, et al. Primary endpoint results of the EVOLVE trial: a randomized evaluation of a novel bioabsorbable polymer-coated, everolimus-eluting coronary stent. J Am Coll Cardiol. 2012;59(15):1362-1370.

88. Meredith IT, Verheye S, Weissman NJ, et al. Six-month IVUS and two-year clinical outcomes in the EVOLVE FHU trial: a randomised evaluation of a novel bioabsorbable polymer-coated, everolimus-eluting stent. EuroIntervention. 2013;9(3):308-315.

89. Ormiston JA, Serruys PW, Regar E, et al. A bioabsorbable everolimuseluting coronary stent system for patients with single de-novo coronary artery lesions (ABSORB): a prospective open-label trial. Lancet. 2008;371(9616):899-907.

90. Onuma Y, Dudek D, Thuesen L, et al. Five-year clinical and functional multislice computed tomography angiographic results after coronary implantation of the fully resorbable polymeric everolimus-eluting scaffold in patients with de novo coronary artery disease: the ABSORB Cohort A trial. JACC Cardiovasc Interv. 2013;6(10):999-1009.

91. Diletti R, Serruys PW, Farooq V, et al. ABSORB II randomized controlled trial: a clinical evaluation to compare the safety, efficacy, and performance of the Absorb everolimus-eluting bioresorbable vascular scaffold system against the XIENCE everolimus-eluting coronary stent system in the treatment of subjects with ischemic heart disease caused by de novo native coronary artery lesions: rationale and study design. Am Heart J. 2012;164(5):654-663.
Medical Devices: Evidence and Research

\section{Publish your work in this journal}

Medical Devices: Evidence and Research is an international, peerreviewed, open access journal that focuses on the evidence, technology, research, and expert opinion supporting the use and application of medical devices in the diagnosis, treatment and management of clinical conditions and physiological processes. The identification of novel

\section{Dovepress}

devices and optimal use of existing devices which will lead to improved clinical outcomes and more effective patient management and safety is a key feature. The manuscript management system is completely online and includes a quick and fair peer-review system. Visit http://www. dovepress.com/testimonials.php to read real quotes from authors. 